\title{
THE IMPACT OF 3CM MODEL WITHIN BLENDED LEARNING TO ENHANCE STUDENTS' CREATIVE 'THINKING ABILITY
}

\author{
Wahyudi Wahyudi $\left(\mathbb{D}\right.$, S.B Waluya $\left(\mathbb{D}\right.$, Hardi Suyitno $\left(\mathbb{D}\right.$, Isnarto Isnarto ${ }^{i}$ \\ Universitas Negeri Semarang (Indonesia) \\ yudhi@staff.uksw.edu, s.b.waluya@mail.unnes.ac.id, bardi.suyitno@mail.unnes.ac.id, isnarto@mail.unnes.ac.id
}

Received November 2018

Accepted September 2019

\section{Abstract}

Creating an enjoyable atmosphere and fostering creativity are the two most required components in learning mathematics. Hence, creativity would enable students to formulate something new. In addition, creativity is one of the most important and highest competencies in Bloom's latest taxonomy. Furthermore, it is necessary to be possessed by everyone including prospective teachers. Not only for producing products in the form of objects, but the term creative also refers to problem solving in mathematic problems. This research is conducted to obtain a detail description regarding the impact of 3CM learning model among blended learning toward the enhancement of students' creative thinking skills in mathematical problem solving. To achieve this goal, a pre-experimental design with one group pre-test post-test design pattern is chosen. Creative thinking skills are measured by test techniques and are emulated with observation techniques. Observations were performed when students worked on the test. The impact of 3CM learning with blended learning seen from test results paired sample $T$ tests with the help of SPSS program a that are acquired from close ended questionnaire techniques. The results show that the average of pre-test is 60.51 and the average of post-test is 75.96. As for the results of paired $\mathrm{T}$ tests is the test got sig value (2-tailed) 0.000 , and hence there was a significant gap among the results of pre-test and post-test. All of these results imply that 3CM learning within blended learning is undoubtedly able to increase students' creativity in solving mathematical problems. This is due to the learning situation and activities which push students to do systematic thinking. It was started by criticizing the enchanting contextual problems, creating creative products based on particular mathematical concepts, and ended by having meaningful reflection.

Keywords - 3CM model, blended learning, creative thinking ability, mathematical problem solving

\section{To cite this article:}

Wahyudi, W., Waluya, S.B., Suyitno, H., \& Isnarto, I. (2020). The impact of 3CM model within blended learning to enhance students' creative thinking ability. Journal of Technology and Science Education, 10(1), 32-46. https://doi.org/10.3926/jotse.588

\section{Introduction}

Creativity is one of the most essential components to be acquired in the $21^{\text {st }}$ century (Mann, 2006; Tindowen, Bassiq \& Cagurangan, 2017). Therefore, the contemporary curriculum nowadays emphasizes on the development of students' creative thinking ability (Vale \& Barbosa, 2015; Sternberg, 2006). Creative thinking ability will support the creativity process in acquiring new knowledge, new approach, new perspective, or even new technique to comprehend and solve problems. The ability to think creatively 
occurs from one's creativity as well as the opportunity to do so (Wahyudi, Waluya \& Rochmad, 2018a). Therefore, creativity becomes something very important and needs to be developed. One way that can be done is through learning mathematics, because mathematics provides an opportunity to develop thinking skills including creative thinking (Shen \& Lai, 2018; Li \& Cheng, 2018).

Mathematics learning has not run properly. Learning mathematics in schools and colleges has not provided an opportunity to develop the ability to think creatively. Learning is more oriented to the amount of material and the acquisition of academic values that focus on cognitive abilities (Parwati, Sudiarta, Mariawan \& Widiana, 2018). Mathematics learning has not provided the opportunity for students to improve reasoning and thinking skills in solving problems (Cracolice, Deming \& Ehlert, 2008; Vyas, Ottis \& Caligiuri, 2011). Mathematics is often considered as unattractive information that is simply forgotten, does not last long in the student brain. The process of assimilation as a process of absorbing new concepts into existing cognitive structures does not occur well because the schemata in the brain are incomplete and not even well formed. Likewise, the accommodation process as a process of forming a new scheme or modifying cognitive structures is not well manifested. Harmony between assimilation with accommodation does not work well that the process of change from one state to another that produces a new balance (equilibration) fails to be transpired. Achieving new equilibrium shows that something has been achieved as feedback and stored in a permanent structure in memory in the form of a scheme.

This condition makes them to have difficulty solving problems that involve thinking skills including creative thinking. The ability to think creatively involves the work of the brain, memory, representation and manipulation (Wahyudi et al., 2018a). This is incompatible with the paradigm of learning mathematics today, where mathematics is close to humans, mathematics is part of human culture (Hersh, 1997; Van, 2002) and is part of social reality (Hersh, 1997; Zevenbergen, Dole \& Wright, 2004). Hence, learning mathematics must be associated with the context of human life and human culture in order to make mathematics easier to remember, imagine, represented, manipulated and assembled in cognitive maps that will allow the students to learn mathematics without having to be burdened with so many mathematical formulas.

Besides having to be contextual, language aspect plays an important role in learning mathematics because the wrong language will give a wrong understanding. An example of that issue is e the mistakes of students in interpreting the words in the problem. Though it won't instantly make the student fail to understand the question, yet inappropriate language will give a different interpretation than what the teacher wants. On this case, the mathematical communication process in working on the problem is not successfully carried out (Zevenbergen et al., 2004; Orton, 2004; Anthony \& Walshaw, 2009). Good language will make mathematics interesting information easy to remember and stored long in the brain of students in a correct and stable scheme. The scheme will be used to solve the problem administered to them. Students need their memory, representation and manipulation to solve a given mathematical problem. This ability is called problem solving ability (Matlin, 2009).

These results are then used to figure out how mathematics learning helps students improving their creativity and problem solving skills through fun, interesting way of learning. Developed by some relevant theories, this study expects to create effective learning situation and provide students an opportunity to think more creatively and critically. The good learning process have to contain meaningful experience and chances for the students to use both their left and right brain. Apart from this perspective, 3CM learning appears with the principle of bringing cool, critical, creative, and meaningful activities to the classroom. This model is given name 3CM (Cool-Critical-Creative-Meaningful) model. This learning model is actually the combination of contextual learning, realistic mathematics, and meaningful learning delivered by Brownell and David Ausubel. The first activity within this learning model is criticizing contextual problems in regard to culture, social life, or anything which are close to the students' life. Such problem is chosen to make the activity becomes meaningful and memorable in students' mind. Also, it was selected to help students in understanding the mathematical concept. If, students are given unfamiliar problems then they may find it difficult to fully comprehend the formulas. As the researcher has mentioned earlier, this 
learning promote the use of right and left hemisphere brain. Right hemisphere brain deals with spiritual feelings including creativity, while the right hemisphere brain deals with the logic (Nurhalim, 2003). By balancing the use of both hemisphere, students will possess higher cognitive ability and creative thinking ability. Creative thinking is basically constructed by logical thinking and divergent thinking. When a person utilizes his/her logical thinking to create something creative, their divergent thinking skills will produce new notion or taught to overcome the issues. On the other side, logical thinking includes rational and coherent process to check and legalize the summary of problem solving that a person has made (Husssin, Harun \& Shukor, 2019).

Moreover, it is compulsory to enrich the learning resouces from which the students get help to obtain data or information used in solving the problem. To do this, teacher can involve technology as one of learning tools and sources in the learning process (Husssin et al., 2019). Thus, teacher should not master the content of materials only, but also pedagogical learning skills to be able to deal with technology. By utilizing technology, it is expected that the learning situation becomes more attractive, effective, and memorable for the students. This learning model that use face-to-face and online interaction in it is usually called Blended learning. Within this learning, students will be trained to find new and creative problem solving, with the help of an endless reference and inspiration that they can access on the internet.

Through this learning method, it is expected that mathematics is introduced and studied in interesting and challenging ways.. It can only be done through comprehensive and interesting learning with a well-established thinking order By using such method, the schema formation process would works properly. Schemata is a cognitive / knowledge structure that describes patterns of thought and behavior that are interrelated and systematic, built from experience, stored in memory and serves to establish and / or shape new knowledge through the process of adaptation (Piaget, 2002; Rumelhart, Norman, Aitkenbcad \& Slack, 1985; Neumann\& Kopcha, 2018; Longo \& Perret, 2018).

Schemata is not a tangible thing that can be seen, but a series of processes in human memory, it has no physical form and cannot be viewed. In the process of thinking, and solving problems, students will apply the schemata that they have, either formal, content or linguistic schemata (Dixon, Zhao, Shin, Wu, Su, Burgess-Brigham et al., 2012; An, 2013). Formal schemata will help and make it easier for students to call and use the schema as a prerequisite knowledge, so that when there is new information, the schema will solidify and update the existing schema. This will make students have better knowledge and gain new knowledge. Content schemata, which is the student's knowledge of what to study will also help students to think better. Because students enter class and learning does not start from something completely empty. They already have experience even though not all are in a stable situation. With a good linguistic schemata, students will find it easier to understand the terms related to the concepts to be learned.

Schemata evolves along with experience (Fischbein,1999; Lashley, 1949), thus the schemata directly proportional to the experience through two processes, namely assimilation and accommodation (Wahyudi, Waluya \& Suyitno, 2018b). Schemata functions to receive, understand, remember, learn, and solve a problem. The way a person solves a problem depends on the scheme that is in his memory. By having a well formation of schemata (formal, content and linguistic schemes), students as prospectus teachers will improve the ability of mathematical creative thinking in solving mathematical problems.

\section{Methodology}

\subsection{Research Model}

Pre experimental design with one group pre test and post test design pattern was applied in this study. One class was selected as experimental class to be given learning with $3 \mathrm{CM}$ learning model. Before studying with $3 \mathrm{CM}$ learning model, students were given pretest to see their initial ability. After following the learning, students were given post test to see the impact of $3 \mathrm{CM}$ learning. The effectiveness of 3CM learning model could be seen from the average difference on pretest and post test results. 


\subsection{Population and Sample Research}

The population in this study is students of Study Program of Primary School Teacher Education class of 2017. The subjects were taken by random sampling technique, with given lottery to represented 7 existing classes, then class A was selected as sample of research.

\subsection{Data Collection Tools}

The data were collected through test, observation, and close ended questionnaire techniques. The test was used to measure the creative thinking ability and the results were compared and analyzed using SPSS through Paired samples T-test. Guidelines for the assessment of creative thinking skills were undertaken with the provisions as in Table 1 below. The results were adapted from Torrance (1995); Torrance (2000); Kim, Lee, Chae, Andersen \& Lawrence (2011); Wahyudi et al. (2018b).

Observation techniques were applied to support the test results data to obtain accurate and complete data. Close ended questionnaire techniques were applied to see students' responses to the learning that has been implemented with the 3CM learning model. This Data is used to strengthen the results of the measurement with the effects of the $3 \mathrm{CM}$ learning model to improve creative thinking skills in solving mathematical problems.

\begin{tabular}{|l|l|l|}
\hline \multicolumn{1}{|c|}{ Aspect } & \multicolumn{1}{|c|}{ Description } & \multicolumn{1}{|c|}{ Explanation } \\
\hline Fluency & $\begin{array}{l}\text { The ability of students to generate many ideas of } \\
\text { true value in a short time }\end{array}$ & $\begin{array}{l}\text { Judging from the idea / idea of the answer and } \\
\text { the number of ideas / ideas of the right } \\
\text { answers are generated }\end{array}$ \\
\hline Flexibility & $\begin{array}{l}\text { The ability of students to produce many } \\
\text { categories of answers that are true value }\end{array}$ & $\begin{array}{l}\text { Viewed from the student's correct answers and } \\
\text { explored in depth in interviews and discussions } \\
\text { so as to elicit another idea / another way to } \\
\text { check again the correct answer given }\end{array}$ \\
\hline Novelty & $\begin{array}{l}\text { Students' ability to use new / unique, or unusual } \\
\text { strategies / answers (different from other } \\
\text { students) to solve problems and be true }\end{array}$ & $\begin{array}{l}\text { Viewed from student answers and compared } \\
\text { with other student's answers to see new things } \\
\text { different from other friends as well as deeply } \\
\text { dug in the interview. }\end{array}$ \\
\hline Elaboration & $\begin{array}{l}\text { The ability of students to explain in detail, } \\
\text { coherent, and coherent to certain mathematical } \\
\text { procedures, answers, or mathematical situations } \\
\text { as a solution to the correct problem that he gave }\end{array}$ & $\begin{array}{l}\text { Judging from the explanation of the correct } \\
\text { answers given and explored in depth through } \\
\text { interviews and discussions }\end{array}$ \\
\hline
\end{tabular}

Table 1. Description of Aspects of Creative Thinking Skills

\subsection{Data Analysis}

Data analysis techniques to see the effect of 3CM learning model was done by comparing the results of pretest and post-test creative thinking ability. Pre-test and post-test results were analyzed, classified and compared using Paired samples T-test with SPSS program.

Data of initial ability of mathematical creative thinking was classified into creative thinking levels (CTL). CTL 3 (Creative), CTL 2 (Creative Enough), CTL 1 (Less Creative). Table 2 below presents the criteria for mathematical creative thinking level.

The test results of creative thinking are strengthened by the observation when students perform the test and close ended questionnaire as a data triangulation process. Findings and new discoveries from the research are derived from comparing the existing research results, theories that support the research, the results of the field records, the observation of the study and the students' response after learning with 3CM Learning model. These results will be used as the final material to make research conclusions and recommendations for the teachers, lecturer and further researchers. 


\begin{tabular}{|c|c|c|}
\hline Interval & Creative Thinking Level (CTL) & Category \\
\hline $68-100$ & CTL 3 & Creative \\
\hline $34-67$ & CTL 2 & Creative Enough \\
\hline $0-33$ & CTL 1 & Less Creative \\
\hline
\end{tabular}

Table 2. Category for determining the level of creative thinking skills

\section{Results and Discussions}

\subsection{Results}

The initial results to be discussed are the quality of learning with the 3CM learning model. The teachers carried out 3CM learning model for approximately 10 weeks (10 meetings), followed by giving a test to the students in face-to-face and online technique. Implementation of 3CM learning was done in seven steps of learning (syntax) which were, motivation, contextual problem, critical issue, problem solving, concept implementation in creative product, confirmation, reflection. Based on these 7 steps of learning, it could be mapped according to the nature of 3CM learning in Table 3.

The model that has been developed is then validated by experts including learning experts, media experts, teaching materials experts and learning resources, as well as learning evaluation experts.

\begin{tabular}{|c|c|c|}
\hline Aspect & Learning Syntax & Explanation \\
\hline Cool & $\begin{array}{l}\text { 1. Motivation } \\
\text { 2. Contextual Problems }\end{array}$ & $\begin{array}{l}\text { Plays a significant role in motivating the students by } \\
\text { giving contextual problems in an enjoyable learning } \\
\text { atmosphere. This initial stage enables the students to } \\
\text { criticize the contextual problems given. }\end{array}$ \\
\hline Critical & $\begin{array}{l}\text { 3. Criticize the Contextual Issues } \\
\text { 4. Troubleshooting }\end{array}$ & $\begin{array}{l}\text { Students are asked to provide the solutions from the } \\
\text { contextual problems given by criticize them first. }\end{array}$ \\
\hline Creative & $\begin{array}{l}\text { 5. Implementation of concepts in } \\
\text { creative products }\end{array}$ & $\begin{array}{l}\text { Students are expected to think about the potential } \\
\text { creative product that might be produced as the } \\
\text { implementation of the previous concept. }\end{array}$ \\
\hline Meaningfull & $\begin{array}{l}\text { 6. Confirmation } \\
\text { 7. Reflection }\end{array}$ & $\begin{array}{l}\text { Teacher and students discuss the result in order to give } \\
\text { meaning from the lesson learned and make a decision in } \\
\text { implementing the concept in the real life. }\end{array}$ \\
\hline
\end{tabular}

Table 3. Aspects in 3CM learning model

\begin{tabular}{|c|l|r|r|r|r|r|c|}
\hline \multirow{2}{*}{ No } & \multirow{2}{*}{ Indicator } & Ideal score & Expert 1 & Expert 2 & Average & PN* (\%) & Category \\
\cline { 5 - 7 } & & 60 & 54 & 55 & 54.5 & $91 \%$ & Very high \\
\hline 2 & Learning activity plan & 30 & 22 & 22 & 22 & $73 \%$ & High \\
\hline 3 & Learning media & 35 & 25 & 25 & 25 & $71 \%$ & High \\
\hline 4 & $\begin{array}{l}\text { Leaching aid and source } \\
\text { instrument }\end{array}$ & 55 & 40 & 41 & 40.5 & $74 \%$ & High \\
\hline
\end{tabular}

Table 4. Results of Expert Assessment for 3 CM Learning Models

*PN $($ Percentage Number $)=\frac{\text { Actual Score }}{\text { Ideal Score }} \times 100 \%$

Based on the feasibility criteria of the developed model, the results obtained were very high and categorized as high $(\mathrm{PN} \geq 61 \%)$ so that the model was feasible to use. The next step is implementing the model on a limited scale to see the practicality of the model. Limited testing is done to one lecturer with 8 students. The results obtained are shown in Table 5 and Table $6 .$.

Based on the results of the assessment and implementation of the model by peers, the value of learning designs (face to face and online), media, and teaching materials developed is calssified as very high and high ( $\mathrm{PN} \geq 61 \%$ ) according to the category, thus the model is considered practical to be used. 


\begin{tabular}{|c|l|r|r|r|}
\hline No & \multicolumn{1}{|c|}{ Indicator } & Ideal Score & \multicolumn{1}{c|}{ Actual Score } & \multicolumn{1}{c|}{ PN* (\%) } \\
\hline 1 & Lesson plan & 60 & 51 & $85 \%$ \\
\hline 2 & Learning media & 55 & 44 & $80 \%$ \\
\hline 3 & Teaching aid and resource & 30 & 23 & $77 \%$ \\
\hline 4 & Learning evaluation instrument & 35 & 26 & $74 \%$ \\
\hline
\end{tabular}

Table 5. Peer assessment (Model Practicality Test)

\begin{tabular}{|c|c|c|c|c|c|c|c|c|c|c|c|}
\hline \multirow{2}{*}{ No } & \multirow{2}{*}{ Aspect Responded } & \multicolumn{10}{|c|}{ Students' respond } \\
\hline & & VD & $\%$ & NG & $\%$ & GE & $\%$ & G & $\%$ & VG & $\%$ \\
\hline 1 & Lesson plan & 0 & 0 & 0 & 0 & 1 & 12,5 & 4 & 50 & 3 & 37.5 \\
\hline 2 & Learning media & 0 & 0 & 0 & 0 & 2 & 25 & 4 & 50 & 2 & 25 \\
\hline 3 & Teaching aid and resource & 0 & 0 & 0 & 0 & 1 & 12.5 & 3 & 37.5 & 4 & 50 \\
\hline 4 & $\begin{array}{l}\text { Learning evaluation } \\
\text { instrument }\end{array}$ & 0 & 0 & 0 & 0 & 1 & 12.5 & 5 & 62.5 & 2 & 25 \\
\hline
\end{tabular}

*Very Good (VG), Good (B), Good Enough (GE), and Not Good (NG), Very Bad (VD)

Table 6. Peer assessment (Model Practicality Test)

\subsection{The Initial Level of Creative Mathematical Thinking}

Before and after learning using 3CM learning models, students are given a pre-test and post-test in order to find out their initial gain ability and end ability in their creative thinking. The mean of pretest and posttest results are 60.52 and 75.96 with the standard deviation of 9.60 and posttest 6.36 with the standard of precast error 1.85 and post-test 1.22 . These results indicate that the creative thinking ability in post-test results is closer to the mean grade in comparison to the pretest results. Thus, the value of the post-test variation is smaller than the pre-test seen from the mean value.

After following the 3CM learning models, there is an increasing number of students who are included in creative and creative enough category. Creative category improved from $7.41 \%$ (2 people) to $40.74 \%$ (11 people). The number of students with creative enough and less creative categories decreased from $92.59 \%$ (25 people) to 59.26\% (16 people). This shows an increase in creative thinking abilities before and after following the learning with 3CM learning.

This result is supported by observations when they were working on test questions. Students work on the problem independently using of problem solving directed to them and managed to create several solutions. Though it is not completely in accordance to the creative thinking aspects yet, it still can be implemented optimally. Descriptions of observation results are seen in Table 8.

To see more about the impact of the application of 3CM learning, it is necessary to test the effect of the model by using paired $T$ tests. Here are the results of the normal test data as shown in Table 9.

The number of students taken as a sample is only 27 people so that the results of normality are taken with the result of normality with Shapiro-Wilk. According to the data in Table 7 we get the Sig value. Pre-test and Post-test values are 0.068 and 0.077 and both are greater than 0.05 so that both data are normally distributed, this is important as normal distribution is the pre-requisite for the conducting the following steps of research, that is: Paired Samples T Test. The results obtained can be seen in Table 10 and Table 11.

\begin{tabular}{|c|r|r|r|r|c|c|}
\hline \multirow{2}{*}{ Interval } & \multicolumn{2}{|c|}{ Pre Test } & \multicolumn{2}{c|}{ Post Test } & \multirow{2}{*}{$\begin{array}{c}\text { Creative Thinking } \\
\text { Level (CTL) }\end{array}$} & Category \\
\cline { 2 - 5 } & \multicolumn{1}{|c|}{ Total } & \multicolumn{1}{c|}{$\mathbf{\%}$} & \multicolumn{1}{c|}{ Total } & \multicolumn{1}{c|}{$\mathbf{0}$} & Creative \\
\hline $68-100$ & 2 & 7.41 & 11 & 40.74 & CTL 3 & Creative Enough \\
\hline $34-67$ & 19 & 70.37 & 16 & 59.26 & CTL 2 & Less Creative \\
\hline $0-33$ & 6 & 22.22 & 0 & 0 & CTL 1 & \\
\hline Average & & 60.52 & & 75.96 & & \\
\hline
\end{tabular}

Table 7. The Category of Students' Creative Thinking Ability Based on Pre -test and Post Test 


\begin{tabular}{|c|r|r|r|}
\hline & \multicolumn{3}{|c|}{ Questions } \\
\cline { 2 - 4 } CTS Aspect & $\mathbf{1}$ & $\mathbf{2}$ & $\mathbf{3}$ \\
\hline Fluency & 20 & 20 & 22 \\
\hline Flexibility & 18 & 16 & 15 \\
\hline Novelty & 12 & 13 & 11 \\
\hline Elaboration & 11 & 11 & 12 \\
\hline
\end{tabular}

Table 8. Observation Results of Student Activities When Working on Tests

\begin{tabular}{|c|c|c|c|}
\hline & \multicolumn{3}{|c|}{ Shapiro-Wilk } \\
\hline & Statistic & df & Sig. \\
\hline Pre Test & .930 & 27 & .068 \\
\hline Post Test & .932 & 27 & .077 \\
\hline
\end{tabular}

Table 9. The Normality Test of Creative Thinking Skills Pre-test and Post-test

\begin{tabular}{|c|c|c|c|c|}
\hline \multicolumn{5}{|c|}{ Paired Samples Correlations } \\
\hline & & $\mathbf{N}$ & Correlation & Sig. \\
\hline Pair 1 & Pre Test \& Post Test & 27 & .777 & .000 \\
\hline
\end{tabular}

Table 10. Paired Samples T-Test Creative Thinking Ability

\begin{tabular}{|c|c|c|c|c|c|c|c|c|c|}
\hline & \multicolumn{5}{|c|}{ Paired Differences } & \multirow[b]{3}{*}{$\mathbf{t}$} & \multirow[b]{3}{*}{ df } & \multirow{3}{*}{$\begin{array}{c}\text { Sig. } \\
\text { (2-tailed) }\end{array}$} \\
\hline & & \multirow[b]{2}{*}{ Mean } & \multirow{2}{*}{$\begin{array}{c}\text { Std. } \\
\text { Deviation }\end{array}$} & \multirow{2}{*}{$\begin{array}{l}\text { Std. } \\
\text { Error } \\
\text { Mean }\end{array}$} & \multicolumn{2}{|c|}{$\begin{array}{l}95 \% \text { Confidence } \\
\text { Interval of the } \\
\text { Difference }\end{array}$} & & & \\
\hline & & & & & Lower & Upper & & & \\
\hline Pair 1 & $\begin{array}{l}\text { Pre Test - } \\
\text { Post Test }\end{array}$ & -15.44 & 6.14 & 1.182 & -17.87 & -13.01 & -13.06 & 26 & .000 \\
\hline
\end{tabular}

Table 11. Test Result of Paired Samples T-test Creative Thinking Ability

Based on data of Table 10 and Table 11 it is found that the value of sig. $0.000<0.05$ and $\mathrm{t}$ arithmetic (13.06) $>\mathrm{t}$ table (2.05). It was discovered that there are significant differences between pretest and post test results. Where post test results were better than the pretest results. Thus, it could be concluded that the application of 3CM learning is effective in improving students' creative thinking skills in solving math problems.

These results are also seen from the difference in the way students think when solving problems before and after learning with 3CM learning. Here is one example of students' questions and outcomes.

The $A B C D$ build is a rectangle. $K$ is located right in the middle of the side $A B$, and $O$ is located right in the middle of the side of the $C D$, length $A B=10 \mathrm{~cm}$ and $B C=5 \mathrm{~cm}$. Determine the size of the $A K C O$ according to the way you think until you get the right result!

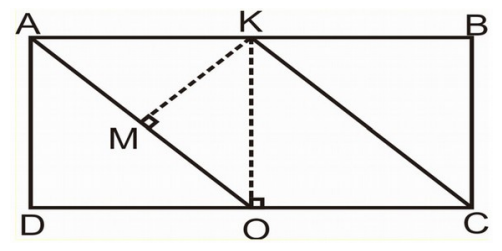




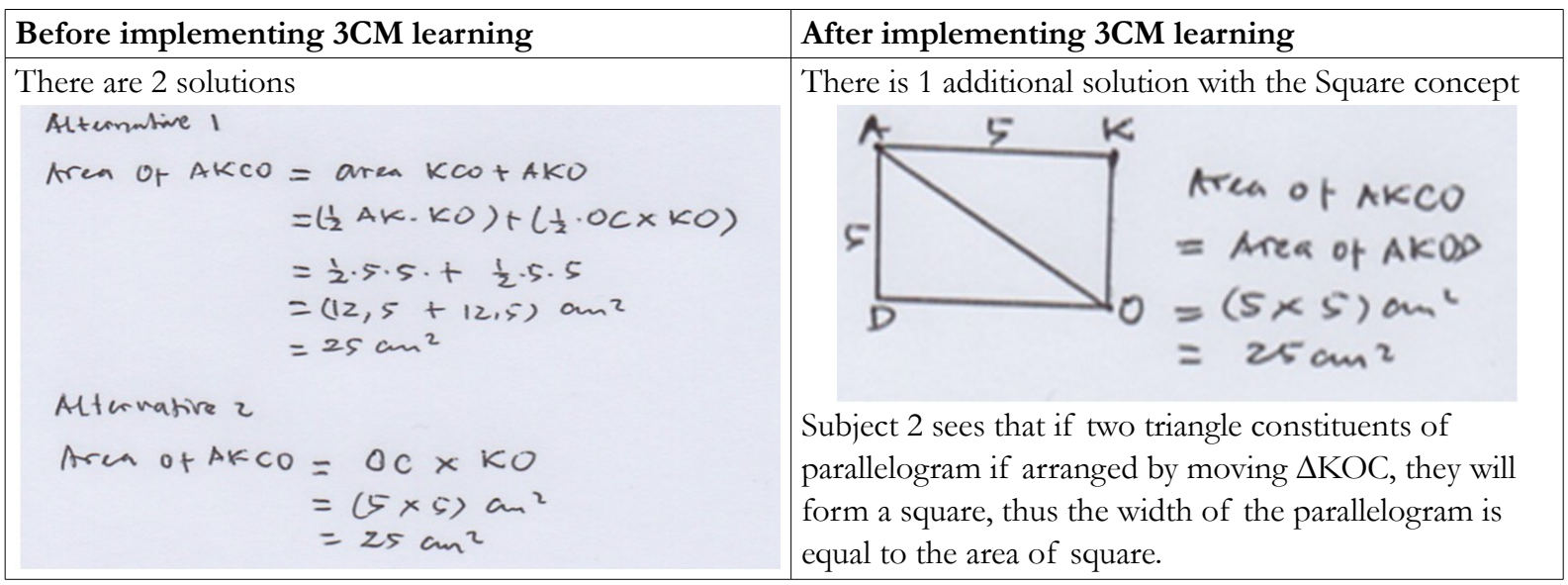

These results indicate that subject with a creative enough category has an incomplete scheme, only focusing on 2 concepts namely parallelogram and triangle. Nevertheless, the assimilation process went well, especially those related to parallelogram thus the concerned was able to provide two solutions to the problem. Subject had not seen other concepts such as rectangles and squares, this caused subject to only produce 2 solutions. What is interesting from the results of interviews is that learning patterns of plane was done partially, not paying attention to the relationship between plane building, so when the subject was asked about the relationship and classification, the subject was confused and cannot describe the relationship.

The following are schematic changes and subject's creative thinking skills after learning with the 3CM learning model.

These results proved that the $3 \mathrm{CM}$ learning model is able to change the subject's schema thus it is able to associate two different concepts, square and parallelogram. This occurrence is related to formal schemes, that is the concept of mastering the prerequisite beforehand in order to understand new concept, that is square and parallelogram. Besides, it is also related to linguistic schemata, that is a schemata in regards to the words or terms used in the problem given, such as congruent, similar shape and size, and similar width. This is what makes subject 2 able to discover other alternatives as the solution, that is by combining the two triangles that build the parallelogram into a square. With the increasing alternative solutions to the problems given, subject's creative thinking ability was also increased, especially the in aspects of fluency, flexibility, and elaboration. While for the novelty aspect, no improvement is found because the answers are still the same as the other subjects.

These results indicate that subject in the less creative category has an unfavorable scheme. This caused subject fails to provide a solution to the problem. The assimilation process did not go well, there were many forgotten concepts even some were unknown to them. What's interesting about the results of the interview is that subject did not like learning mathematics. Subject did not feel comfortable and happy while studying mathematics, even tended to be afraid. This is what caused not many mathematical concepts stored in the subject's memory.

The followings are schematic changes and subject's creative thinking skills after learning with the 3CM learning model. 

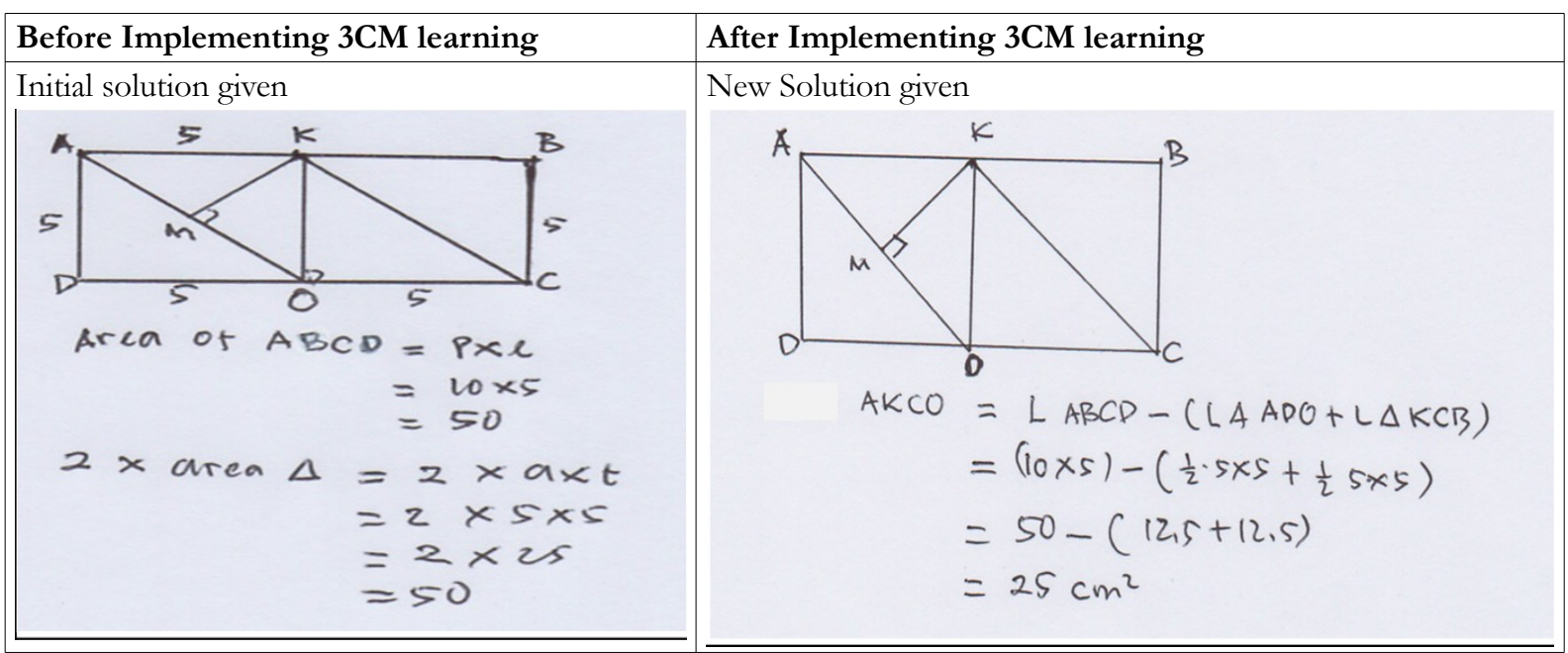

Subject still did not really understand that what was asked was to determine the width of the parallelogram. Because parallelogram images are presented in different forms. The subject only knew the parallelogram given by his teacher. So to determine the area of AKCO, subject used the concept of Rectangle and triangle as above. This solution is also correct.

These results are also supported with students' responses after learning with the 3CM learning model. The response is a result of the following close ended questionnaire.

\begin{tabular}{|l|r|r|r|c|}
\hline \multicolumn{1}{|c|}{ Statement } & $\begin{array}{c}\text { Ideal } \\
\text { Score }\end{array}$ & \multicolumn{1}{|c|}{$\begin{array}{c}\text { Actual } \\
\text { Score }\end{array}$} & PN (\%) & Category \\
\hline I love to follow the Math learning course I've just done & 120 & 105 & $88 \%$ & Very high \\
\hline I am excited in this learning & 120 & 97 & $81 \%$ & Very high \\
\hline I am more freely to study independently with the facilities provided & 120 & 105 & $88 \%$ & Very high \\
\hline $\begin{array}{l}\text { I am easier to learn with the media being prepared and used so that } \\
\text { I am more motivated to study independently }\end{array}$ & 120 & 103 & $86 \%$ & Very high \\
\hline $\begin{array}{l}\text { The lecture activities demanded my creativity in planning a creative } \\
\text { problem solving }\end{array}$ & 120 & 112 & $93 \%$ & Very high \\
\hline $\begin{array}{l}\text { Every time I see a friend who is making a result, it makes me } \\
\text { challenged to make a more creative problem solving }\end{array}$ & 120 & 103 & $86 \%$ & Very high \\
\hline I see every week friends show creativity in solving math problems & 120 & 105 & $88 \%$ & Very high \\
\hline I have benefited from this lecture to increase my creativity & 120 & 111 & $93 \%$ & Very high \\
\hline $\begin{array}{l}\text { Lecturing activities require the ability to think not merely } \\
\text { memorizing }\end{array}$ & 120 & 112 & $93 \%$ & Very high \\
\hline $\begin{array}{l}\text { Lecturing activities require teamwork as a form of collaboration to } \\
\text { produce the work }\end{array}$ & 120 & 109 & $91 \%$ & Very high \\
\hline $\begin{array}{l}\text { Lecturer conducts mentoring to see the development of student } \\
\text { learning in each time the task }\end{array}$ & 120 & 107 & $89 \%$ & Very high \\
\hline $\begin{array}{l}\text { Learning methods are used interesting and facilitate me to learn } \\
\text { how to solve math problems }\end{array}$ & 120 & 99 & $83 \%$ & Very high \\
\hline $\begin{array}{l}\text { Assignments are always related to the material and demanding } \\
\text { student creativity to produce something }\end{array}$ & 120 & 110 & $92 \%$ & Very high \\
\hline $\begin{array}{l}\text { Lecturers always give mentoring when students do assignments in } \\
\text { class }\end{array}$ & 120 & 107 & $89 \%$ & Very high \\
\hline Methods used by lecturers vary according to the topic given & 120 & 114 & $95 \%$ & Very high \\
\hline Well prepared online lecture facilities & 120 & 120 & $100 \%$ & Very high \\
\hline
\end{tabular}




\begin{tabular}{|l|r|r|r|l|}
\hline \multicolumn{1}{|c|}{ Statement } & $\begin{array}{c}\text { Ideal } \\
\text { Score }\end{array}$ & $\begin{array}{c}\text { Actual } \\
\text { Score }\end{array}$ & PN (\%) & Category \\
\hline $\begin{array}{l}\text { Online lecture facilities are provided allowing students to study } \\
\text { independently }\end{array}$ & 120 & 110 & $92 \%$ & Very high \\
\hline $\begin{array}{l}\text { The provided online lecture facilities demanded student creativity to } \\
\text { produce a good work }\end{array}$ & 120 & 103 & $86 \%$ & Very high \\
\hline $\begin{array}{l}\text { With this kind of dissolving system it will increasingly make me } \\
\text { creative to solve the math problem }\end{array}$ & 120 & 107 & $89 \%$ & Very high \\
\hline
\end{tabular}

Table 12. Students' Response on 3CM Learning Model

\subsection{Discussions}

The data analysis and hypothesis testing show that the implementation of 3CM learning model in blended learning is able to enhance students' creative thinking skills in resolving mathematical question. This is due to the enjoyable and context-related activities built within learning situation from which students optimize their learning performance and sharpen their creativity. What was found here is actually relevant with the recent paradigm of mathematics learning saying that mathematics is a part of human culture (Hersh, 1997; Van Oers, 2002) and social situation (Hersh, 1997; Zevenbergen et al., 2004). Similar research conducted by Wahyudi et al. (2018a), it also supported that contextual mathematics learning and appealing learning using scaffolding could push students' motivation in learning mathematics and solving mathematical problems. In the interview sessions, the participants conveyed that their interests of mathematics was not really built by numbers or formulas but more by enchanting, contextual, and imaginable objects. The moment when they played with Phi $(\pi)$ to learn about circumference of a circle was one of the example. At that time, students first listened to a unique, amusing story delivered in Javanese language about two boys talking about Phi $(\pi)$ and its relationship to the circle as follow:

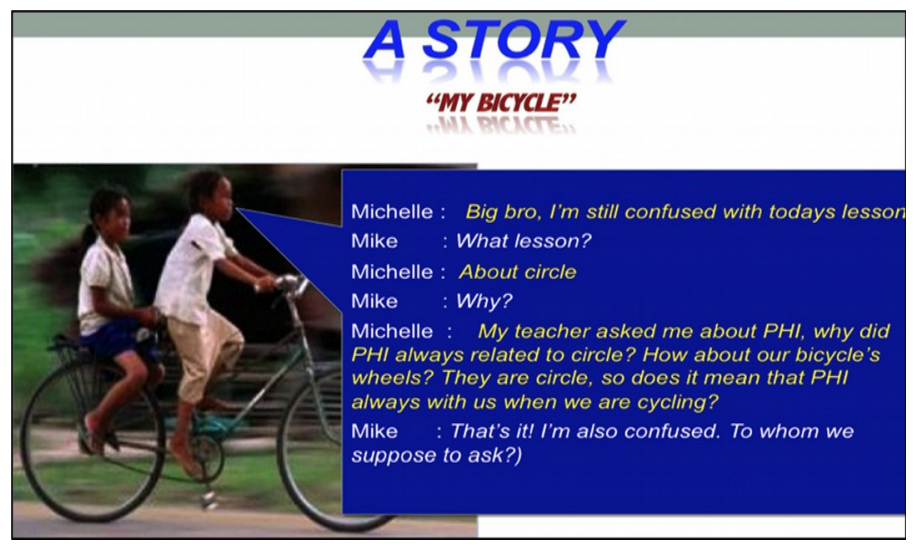

Figure 1. Story as a contextual problem

Students in groups then watched animations sent in WhatsApp class by the lecturers. This aimed to trigger students' critical thinking which was needed in criticizing the mathematical problems. Later, it was proven that the animations was really helpful for the students to comprehend the concept of Phi $(\pi)$ and its connection to the circumference, diameter, and radius of the circle.

After that, the lecturers gave students questions related to use of traveling concept in explaining the working system of gears on the bicycle as well as the implications for the number of wheels turned and the distance traveled by the bicycle. Through these questions, students would learn to criticize and later possessing the ability of applying the concept of traveling on their daily life. Proceeding to the next step of $3 \mathrm{CM}$ learning which is creativity, students were required to create creative products or idea from the concepts they have studied. The assignment itself was to construct mathematical problem-solving stories about the circumference of the circle using power points to be presented with the groups in front of the class. 


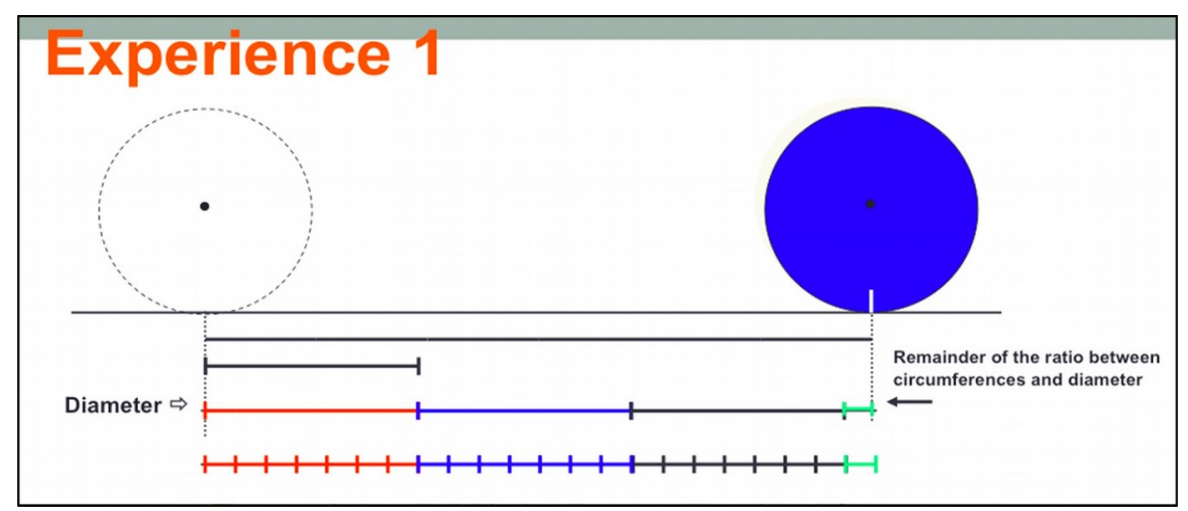

Figure 2. Animation of Phi and around the circle

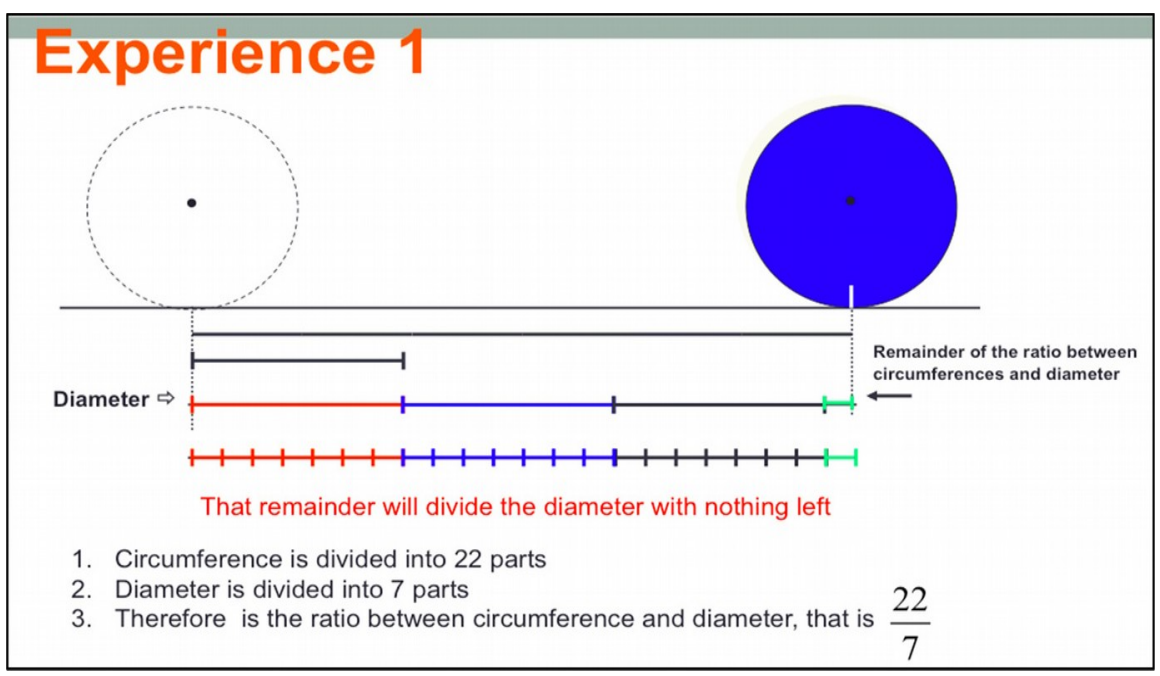

Figure 3. Animation of Phi and around the circle

At the end of the presentation, the teacher together with the students calculated the number of questions, measured the quality of questions from each group, and assessed how worth the solutions were to overcome the problems developed by the groups. The results of this discussion were then used to produce connection among the concept which students got in their life and the advantages obtained from the concept. Through such learning pattern, students were able to relate the reality happened in their surroundings with the activities they undergo, and later utilize it for their future. This is to say, contextual learning like this facilitate students in learning mathematical concept because it feels familiar to them given that it is close to everyday life. This step then is known as confirmation and reflection since the teacher invited students to generate meaning. Furthermore, contextual learning could also be done using online platform such as http://flearn.uksw.edu, particularly in mathematics problem solving course as follow:

After the students watched video about problem criticizing, they were asked to make creative products in the form of power point animations for even number patterns (link to the form of creative work: click here). This kind of activity obviously led the students to the effective learning which was not restricted by time and place, meaning that they can access the learning materials and do the tasks at anywhere and anytime they wanted. Moreover, this online-based activities guided the students to perceive various ways of solving problems which could give them an insight to create new, unique, and creative problem solving. This is in line with the principle of creativity conveyed by Ki Hajar Dewantara. He mentioned that there are $3 \mathrm{~N}$ activities within teaching and learning process, namely Niteni, Nerokke, Nambabi. Niteni means seeing, so to be able to think creatively, the students have to see the objects or problems first and how it is solved. The second stage will be nerokke or imitating the previous problem solving. If they have been able to imitate correctly, they can directly go to the last stage which is nambahi or adding other ways of problem solving they might find. In other words, the main point of this concept is that someone will be increasingly creative if 
s/he is continuously put on the situation which requires them to be so. In addition to that, teacher's teaching style can also affect students' level of creativity (Hsieh, Jang, Hwang \& Chen 2011). If they want the students to be creative, they themselves should be creative in delivering the materials and preparing students' activities. This is because teacher is the role model of students. If the teacher is creative, the students will be triggered to be creative as well (Morais \& Azevedo, 2011). Promoting creativity in the classroom is indeed the perfect way of increasing students' creative thinking skills (Henriksen, 2016).

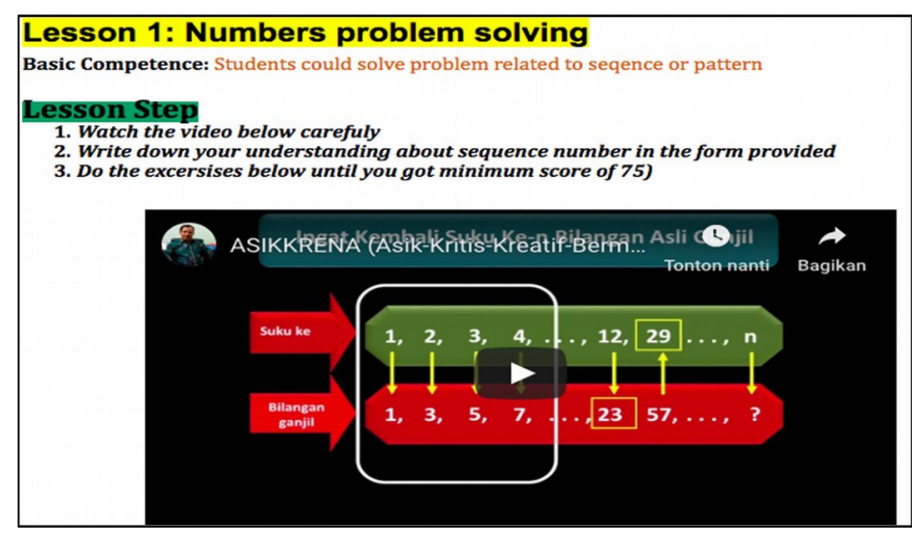

Figure 4. Example of Online Class Display

In regards to this matter, Ki Hajar Dewantara once mentioned that the role of teacher is 'ing ngarso sung tulodo, ing madyo mbangun karso, tut wuri bandayani. It means that teacher should be a good example for the students in any aspect possible, be a motivator for the students to learn, and be able to facilitate students to experience endless exploration of learning. Students therefore will regard learning as something they need and want rather than a compulsion. All of the discussions above have led to the conclusion that students' mathematical problem solving skills, creativity, and independence can be improved through the good roles of teachers, series of opportunity to discuss with group partners, and looking for certain information and data.

Boelens and La Heij (2017) argued that learning runs well if there is an interaction between students, condusive situation, and encouragement from the teachers (Husssin et al., 2019). Students' creativity would also increase within such condition (Soh, 2017; Henriksen, 2016). For instance, they got a chance to present their work followed by positive feedback and motivation from the teachers to create much better work in the future, then it is highly possible that students do better and more creative on the next group work. To build condusive learning situation in the class, the teachers can start by preparing contextual animation media, images, or videos that the students are familiar with, so they can comprehend it easily (Tsai, Horng, Liu, Hu \& Chung, 2015).

\section{Conclusions}

The results of this study prove that 3CM learning within blended learning enhance students' mathematical problem solving and creative thinking skills. It is because such learning offers students a chance to think out-of-the-box and gives students the opportunity to think systematically start by criticizing the interesting contextual problems, produce creative products according to the concept learned and wrap up the lesson with meaningful reflection. Learning activities should be able to make students feel comfortable and love to learn without being overwhelmed with abstract mathematical concepts because it is always presented in the real context of their lives. Their thinking patterns are ordered based on the level of contextual problems given. Students are given the opportunity to create creative products as a way of applying the concepts learned. Class presentation in face-to-face and online forms gives them wider opportunities for exploring and elaborating in order to find diverse problem solving. Creative activities and its examples are provided in online classes to enable students to learn anytime and anywhere. Animations, games and contextual events presented in an online class inspire students to produce creative products as different 
problem solving. Examples of creative activities and products provided by lecturers encourage students to produce other creative products. And finally, Creative lecturers produce creative students.

Based on the results of this study, it is suggested for each lecturer and teacher to give students the opportunity to do something creative including thinking creatively in solving the problems. Hence, the learning focus does not only rely on cognitive ability. The teachers should give more chances for the students to explore and elaborate, so that they are able to produce something creative in solving problems. It can be done by providing a contextual problem that requires them to think diversely instead of identically.

\section{Declaration of Conflicting Interests}

The authors declared no potential conflicts of interest with respect to the research, authorship, and/or publication of this article.

\section{Funding}

The authors received no financial support for the research, authorship, and/or publication of this article.

\section{References}

An, S. (2013). Schema Theory in Reading. Theory and Practice in Language Studies, 3(1), 130-134. https://doi.org/10.4304/tpls.3.1.130-134

Anthony, G., \& Walshaw, M. (2009). Characteristics of Effective Teaching of Mathematics: A View from the West. Journal of Mathematics Education, 2(2), 147-164. Available at:

https://www.creatingrounds.com/uploads/9/6/2/4/96240662/characteristics of effective teaching of mathem ati.pdf (Accessed: July 2018).

Boelens, H., \& La Heij, W. (2017). The development of semantic blocking in children. British Journal of Development Psychology. 35(2) 310-315. https://doi.org/10.1111/bjdp.12178 Available at: https://onlinelibrary.wiley.com/doi/abs/10.1111/bjdp.12178 (Accessed: July 2018).

Cracolice, M.S., Deming, J.C., \& Ehlert, B. (2008). Concept learning versus problem solving: a cognitive difference. Journal of Chemical Education, 85(6), 873. https://doi.org/10.1021/ed085p873

Dixon, L.Q., Zhao, J., Shin, J.-Y., Wu, S., Su, J.-H., Burgess-Brigham, R., et al. (2012). What We Know About Second Language Acquisition: A Synthesis From Four Perspectives. Review of Educational Research, 82(1), 5-60. https://doi.org/10.3102/0034654311433587

Fischbein, E. (1999). Intuitions and schemata in mathematical reasoning. Educational studies in mathematics, 38(1-3), 11-50. https://doi.org/10.1023/A:1003488222875

Henriksen, D. (2016). The seven transdisciplinary habits of minds of creative teachers: An exploratory studi of award winning teachers. Teaching Skills and Creativity, 22, 212-232.

https://doi.org/10.1016/j.tsc.2016.10.007. Available at: https://www.sciencedirect.com/science/article/pii/S1871187116301444 (Accessed: July 2018).

Hersh, R. (1997). What is Mathematics, Really?. London: Jonathan Cape. Available at: http://library1.org/_ads/4A64076F14D4AD813249B43E45AA347E (Accessed: July 2018).

Hsieh, S.W., Jang, Y.R., Hwang, G.J., \& Chen, N.S. (2011). Effects of teaching and learning styles on students' reflection levels for ubiquitous learning. Computers \& Education, 57(1), 1194-1201.

https://doi.org/10.1016/j.compedu.2011.01.004. Available at: https://www.sciencedirect.com/science/article/pii/S0360131511000121 (Accessed: June 2018).

Husssin, W., Harun, J., \& Shukor, N.A. (2019). Online interaction in social learning environment towards critical thinking skill: A framework. Journal of Tecbnology and Science Education, 9(1), 4-12. https://doi.org/10.3926/jotse.544

Kim, K.H., Lee, H., Chae, K., Andersen, L., \& Lawrence, C. (2011). Creativity and Confucianism among American and Korean educators. Creativity Research Journal, 23, 357-371.

https://doi.org/10.1080/10400419.2011.621853 
Lashley, K.S. (1949). Persistent problems in the evolution of mind. The Quarterly Review of Biology, 24(1), 28-42. https://doi.org/10.1086/396806

Li, W., \& Cheng, Y.H.G. (2018). A Study on Engineering Students' Creativity through Art-Infused Curriculum. Eurasia Journal of Mathematics, Science and Technology Education, 14(5), 2009-2024. https://doi.org/10.29333/ejmste/85867

Longo, G., \& Perret, N. (2018). Rhythms, Retention and Protention: Philosophical Reflections on Geometrical Schemata for Biological Time. In Building Theories (245-259). Springer, Cham. https://doi.org/10.1007/978-3-319-72787-5_12

Mann, E. L. (2006). Mathematical creativity and school mathematics: Indicators of mathematical creativity in middle school students 1956. Dissertation Abstracts International Section A: Humanities and Social Sciences, 67, 461. Available at: http://www.fisme.science.uu.nl/publicaties/literatuur/2005 mann creativity.pdf (Accessed: April 2017).

Matlin, M. (2009). Cognition, Seventh Edition. New York: John Wiley \& Sons, Inc. Available at: http://library1.org/ ads/CB8B44A90BFBCC7D64B8B7429EA05F36 (Accessed: April 2018).

Morais, M.F., \& Azevedo, I. (2011). What is a Creative Tecaher and What is a Creative Pupil? Perceptions of Teachers. Procedia Social and Behavioral Sciences, 12, 330-339, https://doi.org/10.1016/j.sbspro.2011.02.042. Available at: https://www.sciencedirect.com/science/article/pii/S1877042811001327 (Accessed: March 2018).

Neumann, K.L., \& Kopcha, T.J. (2018). The Use of Schema Theory in Learning, Design, and Technology. TechTrends, 62(5), 429-431. https://doi.org/10.1007/s11528-018-0319-0

Nurhalim, M.S. (2003). Pembinaan kreativitas menuju era global. Bandung: PT Alumni

Orton, A. (2004). Learning Mathematics (3rd ed.). Issues, Theory and Classroom Pratice. New York: Continuum.

Parwati, N., Sudiarta, I., Mariawan, I., \& Widiana, I. (2018). Local wisdom-oriented problem solving learning model to improve mathematical problem solving ability. Journal of Technology and Science Education, 8(4), 310-320. https://doi.org/10.3926/jotse.401

Piaget, J. (2002). Judgement and reasoning in the child. Routledge. https://doi.org/10.4324/9780203207260

Rumelhart, D.E., Norman, D.A., Aitkenbcad, A.M., \& Slack, J.M. (1985). Issues in cognitive modeling. Representation of Knowledge.

Shen, T., \& Lai, J. (2018). Instructional Design of Creating Creative and Imaginative Works. Eurasia Journal of Mathematics, Science and Technology Education, 14(4), 1509-1517. https://doi.org/10.29333/ejmste/84836

Soh, K. (2017). Fostering student creativity through teacher behaviors. Thinking Skills and Creativity, 23, 58-66. Available at: https://www.sciencedirect.com/science/article/pii/S1871187116301584 (Accessed: July 2018). https://doi.org/10.1016/j.tsc.2016.11.002

Sternberg. R.J. (2006). The Nature of Creativity. Creativity Research Journal, 18(1), 87-98. Available at: https://www.tandfonline.com/doi/abs/10.1207/s15326934cri1801 10 (Accessed: July 2017). https://doi.org/10.1207/s15326934crj1801_10

Tindowen, D.J.C., Bassig, J.M., \& Cagurangan, J.A. (2017). Twenty-First-Century Skills of Alternative Learning System Learners. SAGE Open, 7(3), 1-8. Available at: https://journals.sagepub.com/doi/abs/10.1177/2158244017726116 (Accessed: March 2018). https://doi.org/10.1177/2158244017726116

Torrance, E.P. (1995). The beyonders' in why fly? A philosophy of creativity.Norwood, NJ: Ablex.

Torrance, E.P. (2000). Research review for the Torrance Tests of Creative Thinking Figural and Verbal forms $A$ and B. Bensenville, IL: Scholastic Testing Services. 
Tsai, C.Y., Horng, J.S., Liu, C.H., Hu, D.C., \& Chung, Y.C. (2015). Awakening student creativity: Empirical evidence in a learning environment context. Journal of Hospitality, Leisure, Sport \& Tourism Education, 17, 28-38. Available at: https://www.sciencedirect.com/science/article/pii/S1473837615000180 (Accessed: November 2017). https://doi.org/10.1016/j.jhlste.2015.07.004

Vale, I. \& Barbosa, A. (2015). Mathematics Creativity in Elementary Teacher Training. Journal of the European Teacher Education Network. 10, 101-109. Available at: https://jetenonline.org/index.php/ieten/article/view/70 (Accessed: November 2017).

Van Oers, B. (2002) Educational Forms of Initiation in Mathematical Culture. In Kieran, C., Forman, E., \& Sfard, A. (Eds.), Learning Discourse. Dordrecht: Springer. https://doi.org/10.1007/0-306-48085-9_2

Vyas, D., Ottis, E.J., \& Caligiuri, F.J. (2011). Teaching clinical reasoning and problem-solving skills using human patient simulation. American journal of pharmaceutical education, 75(9), 189. Available at: https://www.aipe.org/doi/full/10.5688/ajpe759189 (Accessed: June 2018). https://doi.org/10.5688/ajpe759189

Wahyudi \& Waluya, B., \& Rochmad. (2018a). Scaffolding Based on Learning Style as An Effort to Increase Mathematical Creative Thinking Skill. The International Journal of Research in Teacher Education, 9(1), 34-44. Available at: http://ijrte.penpublishing.net/makale/441 (Accessed: July 2018).

Wahyudi, Waluya, S.B., \& Suyitno, H. (2018b). Assimilation and Accommodation Processes in Improving Mathematical Creative Thinking with Scaffolding According to Learning Style. Journal of Physics: Conference Series, 1097(1), 012156. IOP Publishing. Available at: http://iopscience.iop.org/article/10.1088/1742-6596/1097/1/012156/pdf (Accessed: October 2018).

Zevenbergen, R., Dole, S., \& Wright, R. J. (2004).Teaching mathematics in primary schools. Crows Nest: Allen \& Unwin.

Published by OmniaScience (www.omniascience.com)

Journal of Technology and Science Education, 2020 (www.jotse.org)

\section{(c) (i) (8)}

Article's contents are provided on an Attribution-Non Commercial 4.0 Creative commons International License. Readers are allowed to copy, distribute and communicate article's contents, provided the author's and JOTSE journal's names are included. It must not be used for commercial purposes. To see the complete licence contents, please visit https://creativecommons.org/licenses/by-nc/4.0/. 